grid provides the chance ( $s i c$ ) for the mental intention to select by choice (sic) the exocytosis of a vesicle from a bouton". Presumably the mental intention is clever enough to choose a large enough number of psychons to excite (say) a face cell (if he will allow these). Most people will object that it is not legitimate to introduce quantum theory in this way: quantum changes occur, as Eccles himself says, by chance and cannot be directional. However, Eccles here presents his hypothesis in full, available for criticism.

Thus the solution to these problems that he wants us to adopt is that in birds and mammals there is an agency called the "mind" (or "soul" ?) which can perform the holistic feat of "reconstructing the picture". For most biologists it will seem unlikely that some special mental process is needed for vision in birds and mammals but not in reptiles, amphibia or fishes or even in bees and octopuses. Eccles does not provide any indication of when this faculty was conferred.

Indeed, further consideration of the miracle is deferred to the last chapter, "The human person". Here, of course, Eccles is no longer dealing with the mind as involved in physiological processes but with the origin of conscious self-awareness. This he very plausibly identifies with ceremonial burial as performed by Neanderthal man 80,000 years ago. It is indeed a mystery how consciousness arose. Eccles's solution is frankly miraculous. He argues that as all "materialist solutions fail to account for our experienced uniqueness, I am constrained to attribute the uniqueness of the Self or Soul to a supernatural spiritual creation each Soul is a new Divine creation which is implanted into the growing foetus at some time between conception and birth".

Following Eccles's palaeontological studies, one wants to know at what stage of human evolution he believes that this intervention began. But the nearest we get to this is his approval, on the last page, of a quotation from the "Christian Darwinist" Lack, including "in the Christian view, a supernatural event took place at the time of man's first appearance, before which our ancestors were protohuman mammals, and after which, through the divine gift of a soul, they were truly human".

These statements will give comfort to religious fundamentalists all over the world. But the fact that they come from a distinguished student of neurophysiology should not be taken to mean that they are generally, or even widely, accepted. What we can all agree is that these are serious and difficult problems of science and philosophy. We can be grateful to Eccles for his lifelong insistence that we should not neglect them, and for presenting them in such a stimulating book.

J. Z. Young is at The Crossroads, Brill, Buckinghamshire HP18 9TL, UK.

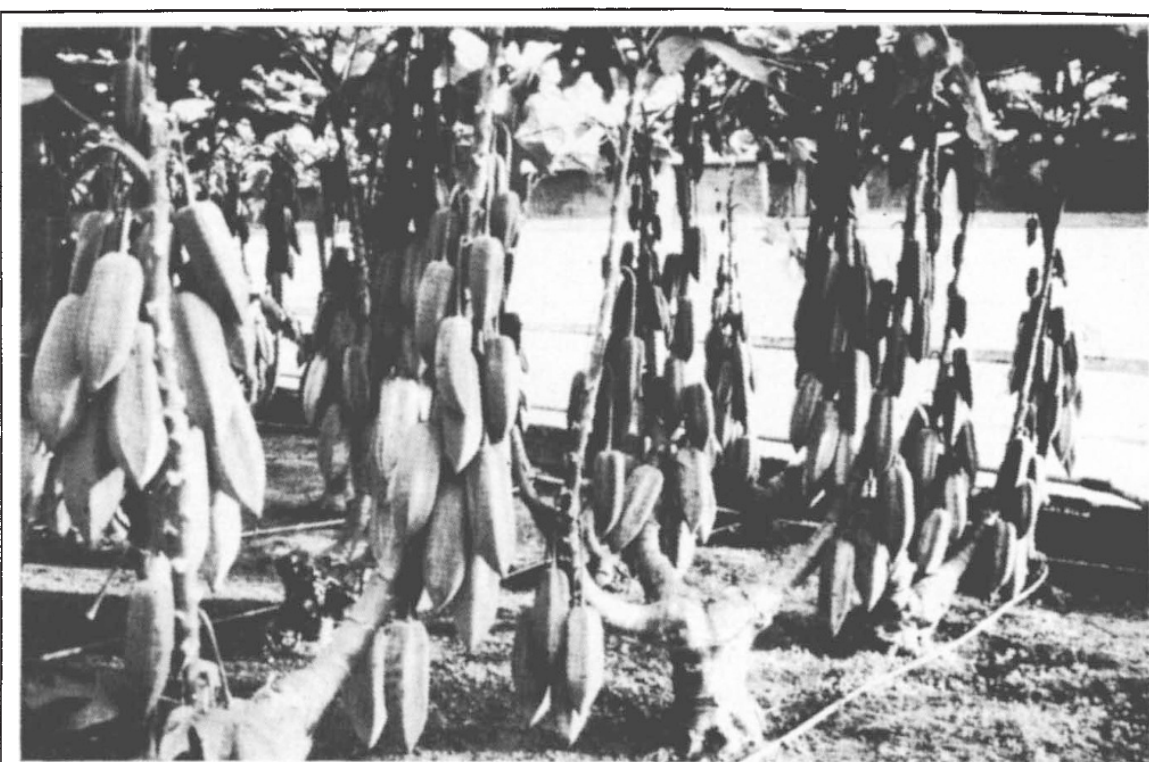

Growing interest - babaco, a highland papaya with a distinctive flavour ("strawberry with a hint of pineapple"), one of the little-known plants of the Andes with potential for worldwide cultivation discussed in Lost Crops of the Incas (National Academy Press, \$20).

\section{A day in the life}

\section{David Harper}

Studying Animal Behaviour: Autobiographies of the Founders. Edited by Donald A. Dewsbury. University of Chicago Press: 1989 . Pp. 312. Pbk $\$ 19.95$, $£ 15.95$.

The Herring Gull's World. By Niko Tinbergen. Lyons and Burford: 1989. Pp. 255. Pbk $\$ 14.95$.

MANY scientists believe that the history of their subject is boring. Cynics may argue that this is because having to find out what people actually did and said is all too likely to disrupt scientists' cosy view of unsullied progress. We would far rather ignore the foibles of our heroes and cast some of our intellectual ancestors as villains, than dirty our minds with facts. One of the best cures for a tedious recital of the bare facts of scientific history is an injection of autobiography, preferably well-laced with gossip. The more objective will argue that autobiography is often inaccurate and self-serving, but those, of course, are two of its most interesting features.

Donald Dewsbury persuaded nineteen animal behaviourists to write about themselves. Their accounts first saw the light of day as Leaders in the Study of Animal Behaviour: Autobiographical Perspectives (Associated University Press, 1985). The only changes in the revised edition are that the book is now a paperback and that dates of birth have been added to the photographs of the authors.

How on earth does one pick out the nineteen most important scientists in animal behaviour? Dewsbury used a panel of six of the good and the wise to make his selection. It would be churlish to contest their choice, since any ethologist or comparative psychologist would produce a different list and the panel selected only one of its own number. Many of the more obvious omissions were unfortunately dead (Harlow, Lack, von Frisch), or had already written similar pieces (Beach, Skinner), or declined to contribute (Aronson, Emlen, Thorpe).

The book is valuable because it tells us what nineteen scientists think we should think about their careers. If only Darwin had explained his inordinate fondness for barnacles! An index would have been a pain to produce, but would have greatly enhanced this book. As it is, I now know lots of anecdotes, but cannot remember to whom they should be attributed.

Another book of interest to historians of ethology re-issued as a paperback is The Herring Gull's World by Niko Tinbergen, first published in 1960. Like a comforting proportion of the contributions to the Dewsbury volume, this book reveals a deep love of nature and tremendous enthusiasm for science. Tinbergen was responsible for many of the great changes in animal behaviour studies since 1960 and it is surprising how well this book has stood the passage of time. But the discussion of motivation could thoroughly confuse readers new to ethology, and some sections now seem very anecdotal and uncritical. This book was never intended as a comprehensive monograph and readers interested in the bird, rather than the history of ethology, will probably look elsewhere. It remains, however, one of the most modest and inspiring books in ethology.

David Harper is in the School of Biological Sciences, University of Sussex, Falmer, Brighton BN1 9QG, UK. 